\title{
An Optimization Study of Carbon Dioxide Absorption into the Aqueous Solution of Monoethanolamine and Tetrabutylphosphonium Methanesulfonate Hybrid Solvent Using RSM-CCD Methodology
}

\author{
Mus'ab Umair Zainul Anuar ${ }^{1}$, Mohd Faisal Taha 1,2,*, Noor Mona Md Yunus ${ }^{2}$, Siti Musliha Mat Ghani ${ }^{2}$ \\ and Azila Idris ${ }^{3,4}$ \\ 1 Fundamental and Applied Science Department, Universiti Teknologi PETRONAS, \\ Seri Iskandar 32610, Perak, Malaysia; musab.umair_25122@utp.edu.my \\ 2 Centre of Research in Ionic Liquids, Universiti Teknologi PETRONAS, Seri Iskandar 32610, Perak, Malaysia; \\ mona.yunus@utp.edu.my (N.M.M.Y.); siti_17007548@utp.edu.my (S.M.M.G.) \\ 3 University Malaya Centre of Ionic Liquids (UMCiL), University Malaya, Kuala Lumpur 50603, Malaysia; \\ azila_idris@um.edu.my \\ 4 Department of Chemistry, Faculty of Science, University Malaya, Kuala Lumpur 50603, Malaysia \\ * Correspondence: faisalt@utp.edu.my; Tel.: +60-05-3687660
}

check for updates

Citation: Zainul Anuar, M.U.; Taha, M.F.; Md Yunus, N.M.; Mat Ghani, S.M.; Idris, A. An Optimization Study of Carbon Dioxide Absorption into the Aqueous Solution of Monoethanolamine and Tetrabutylphosphonium Methanesulfonate Hybrid Solvent Using RSM-CCD Methodology. Processes 2021, 9, 1186. https:// doi.org/10.3390/pr9071186

Academic Editors: Salman Masoudi Soltani and Abhishek Lahiri

Received: 19 May 2021

Accepted: 9 June 2021

Published: 8 July 2021

Publisher's Note: MDPI stays neutral with regard to jurisdictional claims in published maps and institutional affiliations.

Copyright: $\odot 2021$ by the authors. Licensee MDPI, Basel, Switzerland. This article is an open access article distributed under the terms and conditions of the Creative Commons Attribution (CC BY) license (https:// creativecommons.org/licenses/by/ $4.0 /)$.

\begin{abstract}
The main purposes of this project are to assess and to optimize the solubility of carbon dioxide $\left(\mathrm{CO}_{2}\right)$ in an aqueous $30 \mathrm{wt} \%$ monoethanolamine-tetrabutylphosphonium methanesulfonate (MEA-[TBP] $\left[\mathrm{MeSO}_{3}\right]$ ) new hybrid solvent. In this study, the viscosity and density of aqueous MEA$[\mathrm{TBP}]\left[\mathrm{MeSO}_{3}\right]$ hybrid solvents containing different amounts of $[\mathrm{TBP}]\left[\mathrm{MeSO}_{4}\right]$ were determined. Meanwhile, Fourier Transform-Infrared (FT-IR) Spectroscopy was used to determine the presence of carbamate in aqueous MEA-[TBP] $\left[\mathrm{MeSO}_{3}\right]$ to prove that $\mathrm{CO}_{2}$ was absorbed by aqueous MEA[TBP] $\left[\mathrm{MeSO}_{3}\right]$. Response Surface Methodology (RSM) based on central composite design (CCD) was used to design the experiments and explore the effects of three independent parameters on the solubility of $\mathrm{CO}_{2}$ in aqueous MEA-[TBP][MeSO 3$]$. The three independent parameters are concentration of $[\mathrm{TBP}]\left[\mathrm{MeSO}_{3}\right](2-20 \mathrm{wt} . \%)$, temperature $\left(30-60^{\circ} \mathrm{C}\right)$ and pressure of $\mathrm{CO}_{2}(2-30 \mathrm{bar})$. The experimental data was found to fit a quadratic equation using multiple regressions and analyzed using analysis of variance (ANOVA). The final empirical equation in terms of actual factors was deducted as mol fraction $=0.5316-\left(2.76 \times 10^{-4}\right) \mathrm{A}-\left(8.8 \times 10^{-4}\right) \mathrm{B}+\left(8.48 \times 10^{-3}\right) \mathrm{C}+(2.9 \times$ $\left.10^{-5}\right) \mathrm{AB}+\left(2.976 \times 10^{-6}\right) \mathrm{AC}+\left(5.5 \times 10^{-5}\right) \mathrm{BC}-\left(8.4 \times 10^{-5}\right) \mathrm{A}^{2}-\left(3.3 \times 10^{-5}\right) \mathrm{B}^{2}-\left(1.19 \times 10^{-4}\right) \mathrm{C}^{2}$, whereby $\mathrm{A}=$ ionic liquid $\left([\mathrm{TBP}]\left[\mathrm{MeSO}_{3}\right]\right.$ ) concentration, $\mathrm{B}=$ temperature and $\mathrm{C}=\mathrm{CO}_{2}$ pressure. An attempt was made to perform the experiments for solubility of $\mathrm{CO}_{2}$ in aqueous MEA-[TBP] $\left[\mathrm{MeSO}_{3}\right]$ to validate the removal of $\mathrm{CO}_{2}$ predicted by RSM. Based on a validation study, the experimental data showed a percentage error between $0.6 \%$ and $2.11 \%$ as compared to the predicted value of $\mathrm{CO}_{2}$ removal by RSM.
\end{abstract}

Keywords: carbon dioxide; ionic liquid; absorption; Response Surface Methodology (RSM)

\section{Introduction}

The world is in the process of switching to more eco-friendly fuels that contain low carbon, such as natural gas (NG), for energy creation. NG is considered as a non-pollutant energy resource compared to fossil fuels and charcoal, and it is widely used in industrial and domestic applications due to its abundance and low cost. Although the demand for NG for 2020 dropped to $4 \%$ due to the COVID-19 pandemic, it was predicted that in 2021 demand will progressively recover [1,2]. NG collected offshore carries impurities such as $\mathrm{CO}_{2}$, and it is known that $\mathrm{NG}$ contains $20 \% \mathrm{CO}_{2} \cdot \mathrm{CO}_{2}$ from $\mathrm{NG}$ feed gas forms carbamic acid with water vapor present in $\mathrm{NG}$, and this acid can corrode pipelines and other equipment. 
$\mathrm{CO}_{2}$ also causes problems during the liquefaction of NG in multi-cryogenic heat exchange (MCHE) systems and affects the value of final liquefied natural gas (LNG) products [3,4]. In addition, $\mathrm{CO}_{2}$ distributes zero heating value during combustion; therefore, it must be removed to meet the NG quality specifications before it can be handed over to variety of end-users. According to Rufford and colleagues, the specification of NG in pipelines distributed to customers is typically less than $3 \% \mathrm{CO}_{2}$ [4].

One of the most feasible methods to reduce $\mathrm{CO}_{2}$ in the oil and NG industry is through chemical absorption. Currently, the chemical solvents that are widely used as $\mathrm{CO}_{2}$ absorbents are aqueous alkanolamines, in which $\mathrm{CO}_{2}$ is absorbed through the formation of a $\mathrm{CO}_{2}$-amine complex mixture. The $\mathrm{CO}_{2}$-amine complex mixture is then subjected to a 'stripping' process to release the $\mathrm{CO}_{2}$ so it can be kept in $\mathrm{CO}_{2}$ storage. This technology is known as the amine 'scrubbing' process and has been widely utilized as a $\mathrm{CO}_{2}$ capture technology $[3,5]$. Currently, the commercial alkanolamines that are being used in the amine 'scrubbing' process are monoethanolamines (MEAs), methyldiethanolamines (MDEAs), and more recently, triethanolamines (TEAs) due to their re-activity with $\mathrm{CO}_{2}$; they form stable carbamates as intermediates. However, amine $\mathrm{CO}_{2}$ capture does suffer from many inherent drawbacks. The history of amine $\mathrm{CO}_{2}$ capture systems shows that the system suffers from high equipment corrosion rates. Long-term corrosion effects can lead to increases in equipment downtime, loss of production, reduced equipment lifespan, injuries, or even death $[6,7]$.

In the last 20 years, numerous studies have been conducted to improve carbon capture technology and solvent recoverability, many of which have emphasized the shortcomings of conventional aqueous alkanolamine solvents used in 'scrubbing' technology. As an alternative solution to overcome the disadvantages of conventional aqueous alkanolamine solvents, researchers have found that ionic liquids (ILs) are perfect candidates due to their high $\mathrm{CO}_{2}$ solubility. ILs, often regarded as molten salts, are compounds that are completely made up of bulky ions and have a melting point below $100^{\circ} \mathrm{C}[6,8,9]$. They have remarkable properties such as negligible volatility, high thermal stability, non-flammability, tunability and solvation properties. Apart from this, ILs are attractive because of their tunable physicochemical properties. In 1999, initial research on $\mathrm{CO}_{2}$ solubility in ILs conducted by Blanchard and colleagues showed that large amounts of $\mathrm{CO}_{2}$ could be dissolved in imidazolium-based ionic liquids without contaminating the product used [10].

Despite having remarkable properties, ILs also have their drawbacks; these ultimately prevent them from being utilized by the industry. Generally, ILs have high viscosity and are expensive, making them not economically feasible to be used in large-scale production plants [6]. Thus, the addition of small amounts of ILs to aqueous alkanolamines to produce hybrid solvents is a better option, as this would utilize the advantages offered by both ILs and alkanolamines while suppressing their limitations. Considering the widespread use of amine $\mathrm{CO}_{2}$ capture technology, the addition of small quantities of ionic liquid into aqueous alkanolamines would not create any significant changes in existing process designs [11].

Many of the inherent drawbacks were found to be addressed by the incorporation of ILs in aqueous amine solvents. For example, Hasib-Ur Rahman and his colleagues studied the corrosion effects of IL-alkanolamine hybrid solvents on carbon steel 1020 . Their study showed a significant reduction ( $98 \%$ reduced) in the corrosion rate when IL-alkanolamine hybrid solvents were tested with carbon steel 1020. Their study also included the corrosion effects of $\mathrm{CO}_{2}$ gas loading, effects of oxygen in the gas streams, effects of water content, and the effect of varying process conditions; the corrosion results were found to be significantly positive for IL-alkanolamine hybrid solvents [8]. Feng and Camper and colleagues studied the effects of ammonium-based ionic liquid incorporation in aqueous methyldiethanolamine (MDEA) on $\mathrm{CO}_{2}$ absorption performance as well as solvent regeneration efficiency. Their studies showed that higher concentrations $(0-30 \mathrm{wt} \%)$ of ionic liquid in MDEA increased $\mathrm{CO}_{2}$ absorption rate as well as $\mathrm{CO}_{2}$ absorption capacity. The effects of temperature have also been investigated; the $\mathrm{CO}_{2}$ absorption capacity was only slightly affected with an increase in temperature $(298 \mathrm{~K}-318 \mathrm{~K})[5,12]$. 
In this project, MEA and tetrabutylphosphonium methanesulfonate ([TBP][ $\left.\left.\mathrm{MeSO}_{3}\right]\right)$ were selected to be mixed, producing aqueous hybrid solvent for $\mathrm{CO}_{2}$ removal. The MEA concentration was kept constant at $30 \mathrm{wt} \%$ as per typical amine concentrations used in commercialized $\mathrm{CO}_{2}$ absorption technology $[13,14]$. The selection of $[\mathrm{TBP}]\left[\mathrm{MeSO}_{3}\right]$ was based on the results of a screening study using the Conductor-like Screening Model for Real Solvents (COSMO-RS) by Azman [15]. His work aimed to determine ILs that can be mixed with aqueous alkanolamines to form hybrid solvents and to predict the capability of these ILs to capture $\mathrm{CO}_{2}$. His findings revealed that phosphonium-based ILs showed relatively high $\mathrm{CO}_{2}$ capacity in general and moderate cation-anion pairing. In addition, phosphonium-based ionic liquids are generally inexpensive and available commercially on a large scale [16]. The response surface methodology (RSM), based on central composite design (CCD), was employed to optimize and to comprehend the interactions between the operating factors affecting $\mathrm{CO}_{2}$ removal using aqueous $\mathrm{MEA}-[\mathrm{TBP}]\left[\mathrm{MeSO}_{3}\right]$ hybrid solvents with different concentrations of $[\mathrm{TBP}]\left[\mathrm{MeSO}_{3}\right]$.

\section{Materials and Methods}

\subsection{Materials}

Tetrabutylphosphonium methanesulfonate ([TBP][MeSO 3$])$ and monoethanolamine (MEA) were purchased from Merck. Carbon dioxide gas was purchased from Linde with a purity of $99.8 \%$.

\subsection{Density and Viscosity Measurement}

The density of all the aqueous MEA-[TBP][MeSO 3$]$ samples was measured using a Stabinger density viscosity meter (Anton Paar SVM3000, Anton Paar) with a precision of $\pm 0.0001 \mathrm{gcm}^{-3}$. All measurements of the density were performed at $30^{\circ} \mathrm{C}, 45^{\circ} \mathrm{C}$ and $60{ }^{\circ} \mathrm{C}$. The viscosity of the aqueous MEA-[TBP] $\left[\mathrm{MeSO}_{3}\right]$ samples were measured using a TA Instrument DHR-1 rheometer at $30^{\circ} \mathrm{C}, 45^{\circ} \mathrm{C}$ and $60{ }^{\circ} \mathrm{C}$.

\subsection{Solubility of $\mathrm{CO}_{2}$ in Aqueous $\mathrm{MEA}-[\mathrm{TBP}]\left[\mathrm{MeSO}_{3}\right]$}

The $\mathrm{CO}_{2}$ solubility in the aqueous MEA-[TBP] $\left[\mathrm{MeSO}_{3}\right]$ sample was carried out based on the isochoric saturation method [17]. A high-pressure equilibrium cell (EC) with a capacity of $15 \mathrm{~mL}$ made of stainless steel was used to carry out the experiments. The equilibrium cell was attached with a pressure gauge and temperature controller having ranges from 0 to 40 bar and a room temperature of $80^{\circ} \mathrm{C}$, respectively. The schematic of the experimental setup is shown in Figure 1. The temperature inside the equilibrium cell was maintained by a water bath. A pressure gauge was used to measure the pressure inside the system.

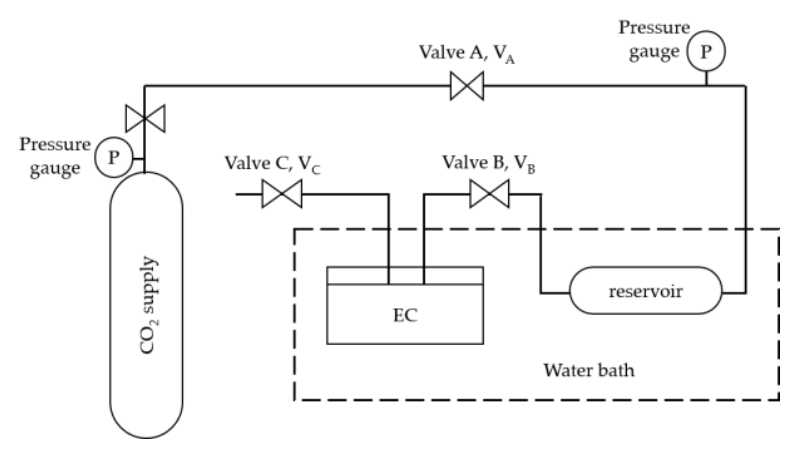

Figure 1. Schematic diagram of $\mathrm{CO}_{2}$ absorption apparatus.

During the experiment, a known quantity of aqueous MEA-[TBP][MeSO 3$]$ was loaded into the equilibrium cell (EC). The EC was degassed by a vacuum pump and the desired temperature inside the $\mathrm{EC}$ was maintained using a chiller. $\mathrm{CO}_{2}$ gas was then introduced into the reservoir of known volume (from $V_{A}$ to $V_{B}$ ) and brought to a constant temperature 
in order to calculate the initial number of moles of $\mathrm{CO}_{2}$ before sending to the EC. The initial number of moles of $\mathrm{CO}_{2}$ was calculated using Equation (1).

$$
n_{\mathrm{CO}_{2}}^{i}=\frac{P_{i} V_{\text {res }}}{Z_{\mathrm{CO}_{2}}^{i} R T_{i}}
$$

where $n_{\mathrm{CO}_{2}}^{i}$ is the initial number of moles of $\mathrm{CO}_{2}$ charged into EC, $P_{i}$ is the initial pressure, $T_{i}$ is the initial temperature, $V_{\text {res }}$ is the volume of the reservoir, $\mathrm{Z}_{\mathrm{CO}_{2}}^{i}$ is the compressibility factor at initial temperature and pressure conditions (calculated from Peng-Robinson equation of state) and $R$ is the universal gas constant.

$\mathrm{CO}_{2}$ was then introduced into $\mathrm{EC}$ by opening $\mathrm{V}_{\mathrm{B}}$. As the absorption of $\mathrm{CO}_{2}$ in aqueous MEA-[TBP][ $\left.\mathrm{MeSO}_{3}\right]$ starts, the pressure inside the cell reduces in continuous manner. The pressure in the system was recorded in 1 min intervals, as the whole system was allowed sufficient time to reach the equilibrium. The time duration varied between 90 and $120 \mathrm{~min}$. At the equilibrium condition, the moles of $\mathrm{CO}_{2}$ left in the cell were calculated using Equation (2).

$$
n_{\mathrm{CO}_{2}}^{e q}=\frac{P_{e q}\left(V_{\text {total }}-V_{s}\right)}{Z_{\mathrm{CO}_{2}}^{f} R T_{e q}}
$$

where $n_{\mathrm{CO}_{2}}^{e q}$ is the number of moles of $\mathrm{CO}_{2}$ left in the system at equilibrium, $P_{e q}$ is the pressure at equilibrium, $T_{e q}$ is the temperature at equilibrium, $V_{\text {total }}$ is the volume of the $\mathrm{CO}_{2}$ absorption system from valve $\mathrm{A}\left(\mathrm{V}_{\mathrm{A}}\right)$ to valve $\mathrm{C}\left(\mathrm{V}_{\mathrm{C}}\right), V_{s}$ is volume of aqueous MEA-[TBP][MeSO $\left.\mathrm{M}_{3}\right]$ and $\mathrm{Z}_{\mathrm{CO}_{2}}^{f}$ is the compressibility factor at equilibrium temperature and pressure conditions (calculated from Peng-Robinson equation of state). The number of moles of $\mathrm{CO}_{2}$ absorbed $\left(n_{\mathrm{CO}_{2}}^{a b s}\right)$ by aqueous MEA-[TBP] $\left[\mathrm{MeSO}_{3}\right]$ is given by Equation (3).

$$
n_{\mathrm{CO}_{2}}^{a b s}=n_{\mathrm{CO}_{2}}^{e q}-n_{\mathrm{CO}_{2}}^{i}
$$

where $n_{\mathrm{CO}_{2}}^{e q}$ is the number of moles of $\mathrm{CO}_{2}$ left in the system at equilibrium and $n_{\mathrm{CO}_{2}}^{i}$ is the initial number of moles of $\mathrm{CO}_{2}$ charged into EC. Meanwhile, the solubility of $\mathrm{CO}_{2}$ expressed in mole fraction $\left(x_{2}\right)$ was calculated according to Equation (4).

$$
x_{2}=\frac{n_{\mathrm{CO}_{2}}^{a b s}}{n_{\mathrm{CO}_{2}}^{a b s}+n_{s}}
$$

where $n_{\mathrm{CO}_{2}}^{a b s}$ is the number of moles of $\mathrm{CO}_{2}$ absorbed by aqueous MEA-[TBP][MeSO$\left.{ }_{3}\right]$ and $n_{s}$ is the number of moles of aqueous MEA-[TBP][MeSO${ }_{3}$ ] used in the system.

\subsection{Optimization Study of $\mathrm{CO}_{2}$ Solubility in the Aqueous MEA-[TBP][MeSO $\mathrm{M}_{3}$ S Solvent Using RSM}

The response surface methodology (RSM) was developed based on the central composite design (CCD), with $\mathrm{CO}_{2}$ as the dependent variable (responses), using Design-Expert software version 12. The factors of experimental design, including IL ([TBP][MeSO $\left.{ }_{3}\right]$ ) concentration $(\mathrm{wt} \%)$, temperature $\left({ }^{\circ} \mathrm{C}\right)$ and pressure of $\mathrm{CO}_{2}(\mathrm{bar})$, were selected. The $\mathrm{CCD}$ was performed using a $2^{3}$ face centered design and, according to the three levels and three variable concepts, 20 experimental points in random order were adopted in this design. The three independent variables were prescribed into three levels (low, basal and high) and coded values $(-1,0,+1)$. CCD was chosen because the design includes a repetition of center points that is used to calculate the experimental error, providing more reliable data. A total of 20 runs of experiments were performed, and the experimental results were fitted to regression model equation.

In this study, the independent variable for the IL (TBP][$\left.\left[\mathrm{MeSO}_{3}\right]\right)$ concentration was represented by variable $\mathrm{A}$, while the temperature was denoted as $\mathrm{B}$ and the pressure of $\mathrm{CO}_{2}$ was denoted as $\mathrm{C}$. The range and levels of the processing parameters involved are shown in Table 1. 
Table 1. Independent variables and concentration levels for response surface study.

\begin{tabular}{ccccc}
\hline \multirow{2}{*}{ Factors } & Unit & \multicolumn{3}{c}{ Levels } \\
\cline { 3 - 5 } & & $\mathbf{- 1}$ & $\mathbf{0}$ & $\mathbf{+ 1}$ \\
\hline A: $\mathrm{IL}\left([\mathrm{TBP}]\left[\mathrm{MeSO}_{3}\right]\right)$ concentration & $\mathrm{wt}^{\circ} \%$ & 2 & 10 & 20 \\
\hline B: Temperature & ${ }^{\circ} \mathrm{C}$ & 30 & 45 & 60 \\
\hline C: Pressure of $\mathrm{CO}_{2}$ & bar & 2 & 16 & 30 \\
\hline
\end{tabular}

\subsection{FT-IR Spectroscopy}

FT-IR analysis was carried out for aqueous MEA, aqueous $20 \mathrm{wt} \%$ [TBP][ $\left.\mathrm{MeSO}_{3}\right]$ and aqueous MEA-[TBP] $\left[\mathrm{MeSO}_{3}\right]$, before and after their exposure to $\mathrm{CO}_{2}$, with the main purpose of identifying new bands of the carbamate species that show that $\mathrm{CO}_{2}$ is chemically absorbed by the samples as amine reacts with $\mathrm{CO}_{2}$ to form carbamate [18]. Each spectrum was recorded in spectral ranging from 4000 to $550 \mathrm{~cm}^{-1}$.

\section{Results}

\subsection{Density and Viscosity}

The effect of IL ([TBP][MeSO 3$]$ ) concentration and temperature on the density of aqueous MEA-[TBP][$\left[\mathrm{MeSO}_{3}\right]$ solvent was studied. Figure 2 shows the significant effect of IL concentration and temperature on the density of the hybrid solvents. As expected, the density of the aqueous MEA-[TBP] $\left[\mathrm{MeSO}_{3}\right.$ ] solvent increased with the increased of IL concentration due to more molecules present in the hybrid solvent at constant volume. The aqueous MEA, without the presence of IL, showed the lowest density as compared to the hybrid solvents. Meanwhile, as expected, the density of the hybrid solvent was found to be decreased by increasing the temperature. This is due to the increase in volume, as heat causes the molecules to move faster and move apart as they receive the high kinetic energy of the increasing temperature, which in turn reduces the density.

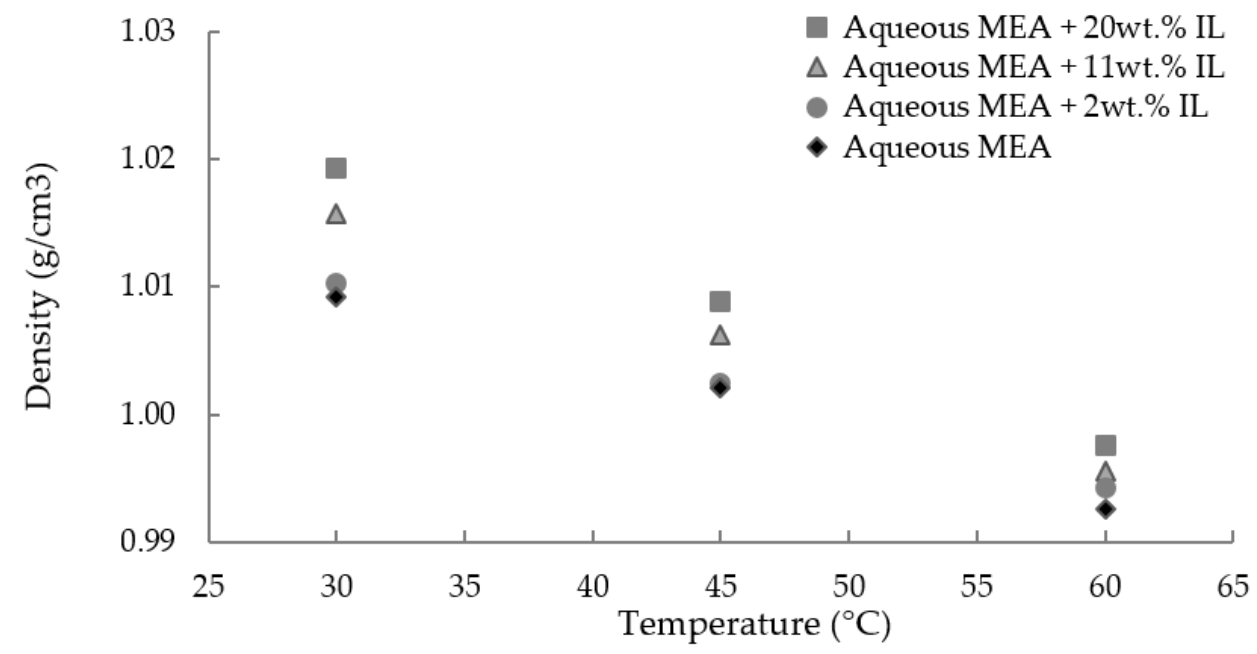

Figure 2. Density of aqueous MEA and aqueous MEA-[TBP][ $\left.\mathrm{MeSO}_{3}\right]$ solvent at different IL concentrations and temperatures.

The effect of IL concentration and temperature on the viscosity of aqueous MEA[TBP] $\left[\mathrm{MeSO}_{3}\right]$ solvent was studied. Figure 3 presents the plot graph of viscosity of the hybrid solvent with different concentrations of IL and at different temperatures. As shown in the figure, the viscosity of all absorbents used in this study was low (less than 0.05 Pa.s), which could help facilitate the mass transfer for $\mathrm{CO}_{2}$ absorption [13]. Figure 3 also demonstrates, as expected, that the viscosity of the hybrid solvent decreases with increasing temperature. Higher thermal energy causes the molecules to become more mobile and weakens the molecular resistance. Meanwhile, the increase in concentration of 
IL causes the increase of the internal resistance in the mixture, which in turn increases the viscosity of the hybrid solvent [19].

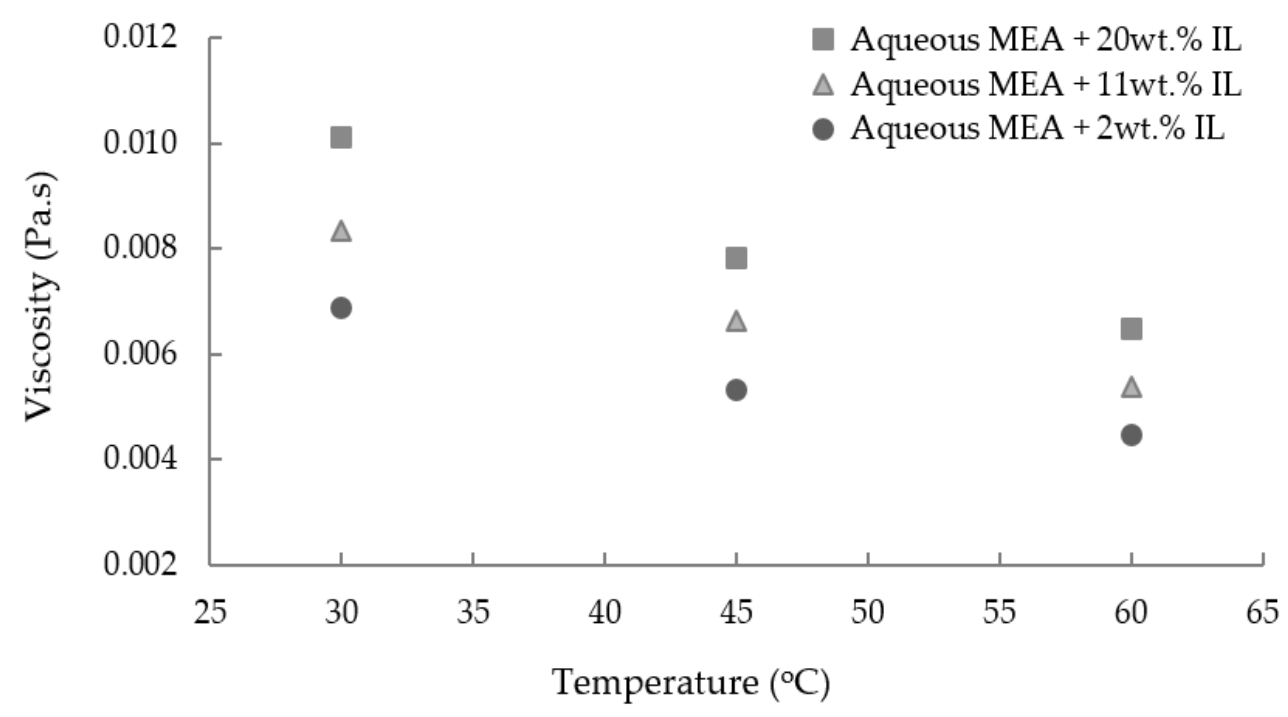

Figure 3. Viscosity of aqueous MEA-[TBP] $\left[\mathrm{MeSO}_{3}\right]$ solvent at different $\mathrm{IL}$ concentrations and temperatures.

\subsection{FT-IR Spectroscopy}

Figure 4 shows the FT-IR spectrum in the region from 800 to $1800 \mathrm{~cm}^{-1}$ for samples before and after the $\mathrm{CO}_{2}$ solubility experiment, while Table 2 shows important band assignment analysis of the FT-IR spectra. The wavenumber regions from 650 to $800 \mathrm{~cm}^{-1}$ and from 1800 to $4000 \mathrm{~cm}^{-1}$ do not provide useful information for interaction between samples and $\mathrm{CO}_{2}$. In Figure 4a, no new band emergence was observed for $20 \mathrm{wt} . \%$ [TBP][MeSO 3 ] aqueous sample after $\mathrm{CO}_{2}$ exposure, indicating physical absorption of $\mathrm{CO}_{2}$ in the aqueous IL [10]. As shown in Figure 4b,c, emergence of new bands at 1568, 1486 and $1312 \mathrm{~cm}^{-1}$ was observed in the sample of aqueous MEA and aqueous MEA-[TBP][MeSO $\mathrm{M}_{3}$ ] after the $\mathrm{CO}_{2}$ solubility experiment. These bands are assigned to carbamate's $\mathrm{COO}^{-}$ asymmetric and $\mathrm{COO}^{-}$symmetric stretching and $\mathrm{N}^{-} \mathrm{COO}^{-}$stretching vibration. It should be noted that the bands at $955 \mathrm{~cm}^{-1}$ (C-N-H out-of-plane wagging and $\mathrm{C}-\mathrm{NH}_{2}$ twisting) and $1362 \mathrm{~cm}^{-1}\left(\mathrm{NH}_{2}\right.$ twisting) for MEA in the samples decreased upon $\mathrm{CO}_{2}$ exposure. There was also protonation of MEA, resulting in a C-N stretching mode shift from 1074 to $1066 \mathrm{~cm}^{-1}$. Similar observations where stable carbamate is formed when MEA reacted with $\mathrm{CO}_{2}$ have been reported $[18,20,21]$. This chemical bonded formation can lead to large amounts of energy required for regeneration of the amine [4].

Table 2. FT-IR absorption band assignment.

\begin{tabular}{cc}
\hline Band $\mathbf{( \mathbf { c m } ^ { - 1 } )}$ & Assignment \\
\hline 1568 & $\mathrm{COO}^{-}$(carbamate) \\
1483 & $\mathrm{COO}^{-}$(carbamate) \\
1380 & $\mathrm{C}-\mathrm{O}\left(\mathrm{CO}_{2} / \mathrm{CO}_{3}^{2-}\right.$ physical adsorption) \\
1362 & $\mathrm{NH}_{2}$ (MEA) \\
1312 & $\mathrm{~N}-\mathrm{COO}^{-}$(carbamate) \\
1074 & C-N stretching (MEA) \\
1066 & $\mathrm{C}-\mathrm{N}$ (protonated MEA, carbamate) \\
955 & C-NH $\mathrm{N}_{2}$ (MEA) \\
\hline
\end{tabular}


(a) Aqueous 20wt.\% IL

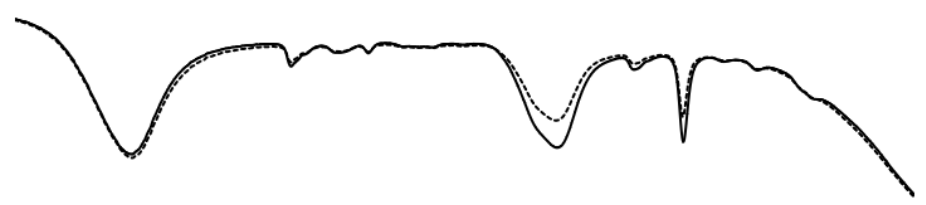

(b) Aqueous MEA

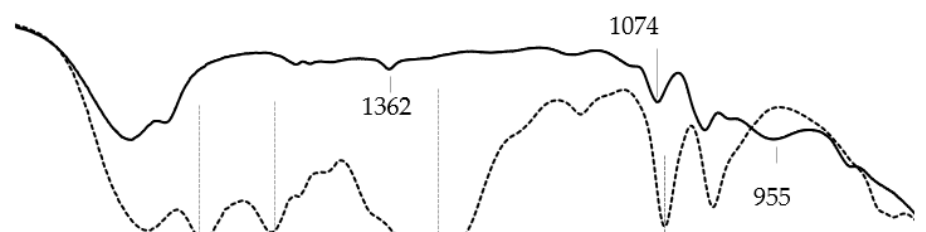

(c) Aqueous MEA + 20wt.\% IL

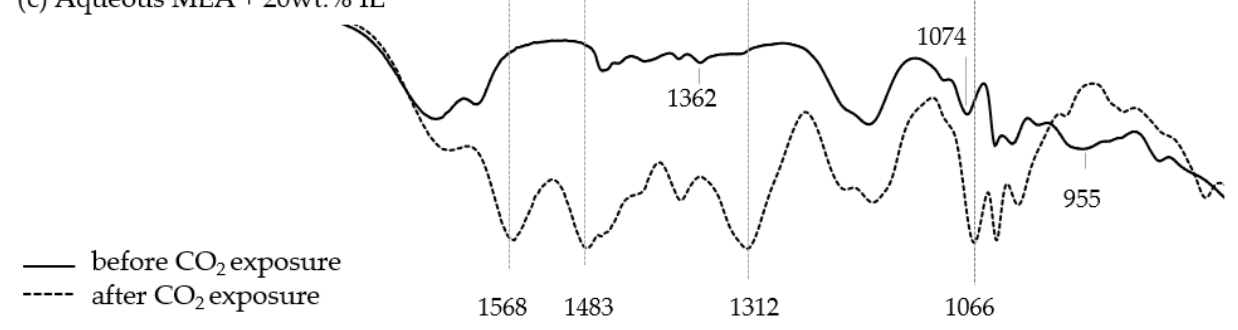

\begin{tabular}{|c|c|c|c|c|c|}
\hline 1800.00 & 1600.00 & 1400.00 & 1200.00 & 1000.00 & 800.00 \\
\hline
\end{tabular}

Figure 4. FT-IR spectra of samples: (a) aqueous $20 \mathrm{wt} \%$ of $\mathrm{IL} ;(\mathbf{b})$ aqueous $30 \mathrm{wt} \%$ of MEA and (c) aqueous MEA + $20 \mathrm{wt} \%$ IL before (solid line) and after (dash line) exposure to $\mathrm{CO}_{2}$.

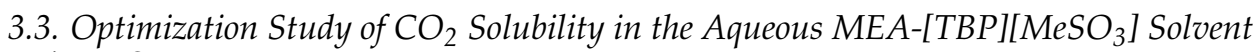 Using RSM}

In this study, response surface methodology (RSM) based on the central composite design (CCD) was employed to analyze the effects of three parameters, i.e. IL [TBP][ $\mathrm{MeSO}_{3}$ ] concentration, temperature and $\mathrm{CO}_{2}$ pressure, on the absorption of $\mathrm{CO}_{2}$ in aqueous MEA[TBP][ $\left.\mathrm{MeSO}_{3}\right]$ solvent. The $\mathrm{CCD}$ was performed using a $2^{3}$ face centered design according to the three levels and three variable concepts, in which 20 experimental runs in random order were adopted. Table 3 shows the parameters of each run that were generated using the central composite design (CCD) method and the experimental response data, which were degree $\mathrm{CO}_{2}$ solubility in hybrid solvent.

\subsubsection{Analysis of Variance (ANOVA)}

The ANOVA analysis as presented in Table 4 indicates that the quadratic model is significant to represent the $\mathrm{CO}_{2}$ removal using the aqueous MEA-[TBP][MeSO$\left.{ }_{3}\right]$ solvent. The regression model is as follows:

$$
\begin{gathered}
\text { Mol fraction }=0.5316-\left(2.76 \times 10^{-4}\right) \mathrm{A}-\left(8.8 \times 10^{-4}\right) \mathrm{B}+\left(8.48 \times 10^{-3}\right) \mathrm{C} \\
+\left(2.9 \times 10^{-5}\right) \mathrm{AB}+\left(2.976 \times 10^{-6}\right) \mathrm{AC}+\left(5.5 \times 10^{-5}\right) \mathrm{BC}-\left(8.4 \times 10^{-5}\right) \mathrm{A}^{2} \\
-\left(3.3 \times 10^{-5}\right) \mathrm{B}^{2}-\left(1.19 \times 10^{-4}\right) \mathrm{C}^{2}
\end{gathered}
$$

As can be seen in Table 4, the calculated F-value of 90.84 and $p$-value $<0.0001$ indicate that the model was significant with low probability of error in this study. Correspondingly, the calculated lack of fit was 4.87 , which was not significantly relative to the pure error. A possibility of $5.36 \%$ of large lack of fit F-value may occur due to noise. $p$-values less than 0.0500 indicate model terms are significant [22]. In this case B, C, BC and $C^{2}$ are significant model terms. The most significant model term was pressure, with the highest F-value of 
668.98. The factor of IL concentration (A), with $p$-value of 0.0985 , does not give significant effect towards the $\mathrm{CO}_{2}$ solubility response.

Table 3. Experimental layout and results of $2^{3}$ face centered central composite design.

\begin{tabular}{|c|c|c|c|c|c|}
\hline \multirow{2}{*}{ Standard } & \multirow{2}{*}{ A: IL Concentration (wt $\%$ ) } & \multirow{2}{*}{ B: Temperature $\left({ }^{\circ} \mathrm{C}\right)$} & \multirow{2}{*}{$\mathrm{C}: \mathrm{CO}_{2}$ Pressure (bar) } & \multicolumn{2}{|c|}{ Mol Fraction } \\
\hline & & & & Experimental & Predicted \\
\hline 1 & 2 & 30 & 2 & 0.505 & 0.496 \\
\hline 2 & 20 & 30 & 2 & 0.463 & 0.474 \\
\hline 3 & 2 & 60 & 2 & 0.373 & 0.387 \\
\hline 4 & 20 & 60 & 2 & 0.382 & 0.380 \\
\hline 5 & 2 & 30 & 30 & 0.670 & 0.674 \\
\hline 6 & 20 & 30 & 30 & 0.665 & 0.653 \\
\hline 7 & 2 & 60 & 30 & 0.620 & 0.611 \\
\hline 8 & 20 & 60 & 30 & 0.595 & 0.605 \\
\hline 9 & 2 & 45 & 16 & 0.573 & 0.573 \\
\hline 10 & 20 & 45 & 16 & 0.565 & 0.559 \\
\hline 11 & 11 & 30 & 16 & 0.598 & 0.604 \\
\hline 12 & 11 & 60 & 16 & 0.539 & 0.526 \\
\hline 13 & 11 & 45 & 2 & 0.462 & 0.448 \\
\hline 14 & 11 & 45 & 30 & 0.643 & 0.650 \\
\hline 15 & 11 & 45 & 16 & 0.573 & 0.572 \\
\hline 16 & 11 & 45 & 16 & 0.564 & 0.572 \\
\hline 17 & 11 & 45 & 16 & 0.560 & 0.572 \\
\hline 18 & 11 & 45 & 16 & 0.578 & 0.572 \\
\hline 19 & 11 & 45 & 16 & 0.577 & 0.572 \\
\hline 20 & 11 & 45 & 16 & 0.569 & 0.572 \\
\hline
\end{tabular}

Table 4. ANOVA for quadratic modelling of $\mathrm{CO}_{2}$ removal.

\begin{tabular}{|c|c|c|c|c|c|c|}
\hline Source & Sum of Squares & $\mathrm{dF}$ & Mean Square & F-Value & $p$-Value & \\
\hline Model & 0.1242 & 9 & 0.0138 & 90.84 & $<0.0001$ & significant \\
\hline A-IL Concentration & 0.0005 & 1 & 0.0005 & 3.32 & 0.0985 & \\
\hline B-Temp & 0.0154 & 1 & 0.0154 & 101.17 & $<0.0001$ & \\
\hline C-Pressures & 0.1016 & 1 & 0.1016 & 668.98 & $<0.0001$ & \\
\hline $\mathrm{AB}$ & 0.0001 & 1 & 0.0001 & 0.7909 & 0.3947 & \\
\hline $\mathrm{AC}$ & $1.125 \times 10^{-6}$ & 1 & $1.125 \times 10^{-6}$ & 0.0074 & 0.9331 & \\
\hline $\mathrm{BC}$ & 0.0011 & 1 & 0.0011 & 7.12 & 0.0236 & \\
\hline $\mathrm{A}^{2}$ & 0.0001 & 1 & 0.0001 & 0.8417 & 0.3805 & \\
\hline $\mathrm{B}^{2}$ & 0.0001 & 1 & 0.0001 & 0.9697 & 0.3480 & \\
\hline$C^{2}$ & 0.0015 & 1 & 0.0015 & 9.84 & 0.0106 & \\
\hline Residual & 0.0015 & 10 & 0.0002 & & & \\
\hline Lack of Fit & 0.0013 & 5 & 0.0003 & 4.87 & 0.0536 & not significant \\
\hline Pure Error & 0.0003 & 5 & 0.0001 & & & \\
\hline Cor Total & 0.1257 & 19 & & & & \\
\hline
\end{tabular}

\subsubsection{Fit Statistics}

Fit summary output analysis showed that the quadratic model was statistically significant to represent the mol fraction of $\mathrm{CO}_{2}$ solubility response (Table 5). The high value of $R^{2}(0.9879)$ indicates that the data fit the model very well. The predicted $R^{2}(0.8443)$ was in acceptable agreement with the adjusted $R^{2}(0.9770)$, as the difference was less than 0.2 . 
Table 5. Fit statistics of Response Surface Quadratic Model.

\begin{tabular}{cc}
\hline Factors & Value \\
\hline Std. Dev. & 0.0123 \\
Mean & 0.5537 \\
Coefficient of variance percentage & 2.23 \\
$\mathrm{R}^{2}$ & 0.9879 \\
Adjusted $\mathrm{R}^{2}$ & 0.9770 \\
Predicted $\mathrm{R}^{2}$ & 0.8443 \\
Adequate Precision & 33.7600 \\
\hline
\end{tabular}

Figure 5a shows the actual against the predicted value plot for $\mathrm{CO}_{2}$ solubility, where the residuals were generally placed on a straight line and normally distributed. The actual value and predicted values for all responses were close to each other, as shown in Table 3. These results confirmed that the predicted and actual values were in good agreement, with high acceptability of the models [23]. The adequate precision measures the signal to noise ratio, and the ratio value of 33.76 indicated an adequate signal (adeq precision $>4$ ) [24].

(a)

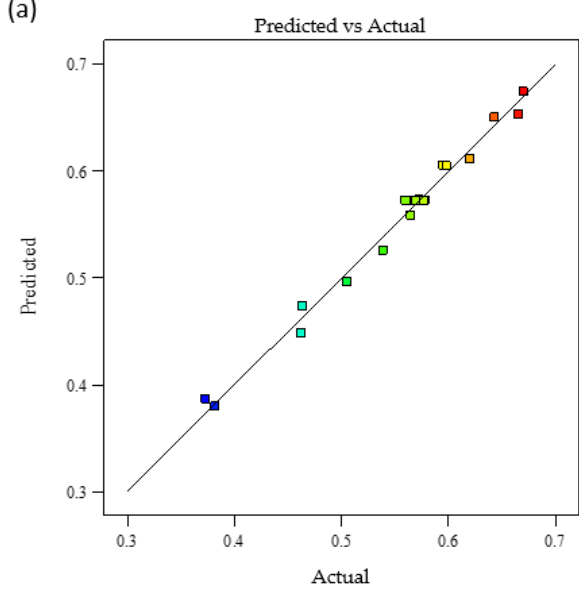

(c)

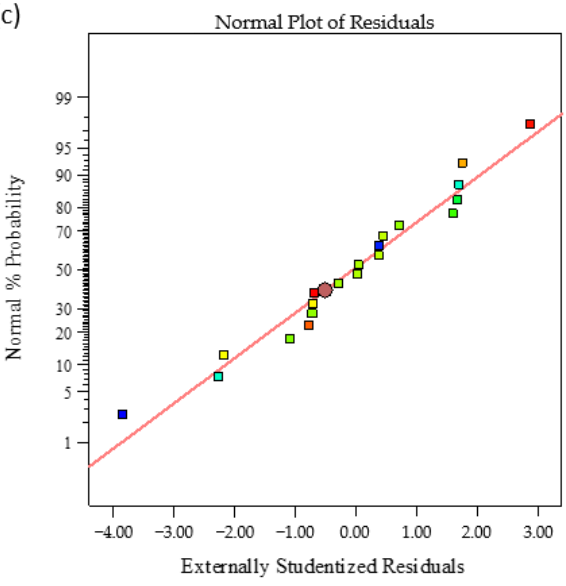

(b)

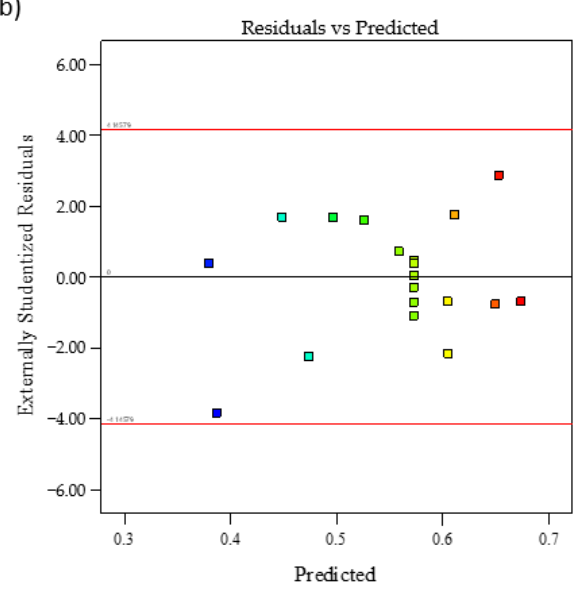

(d)

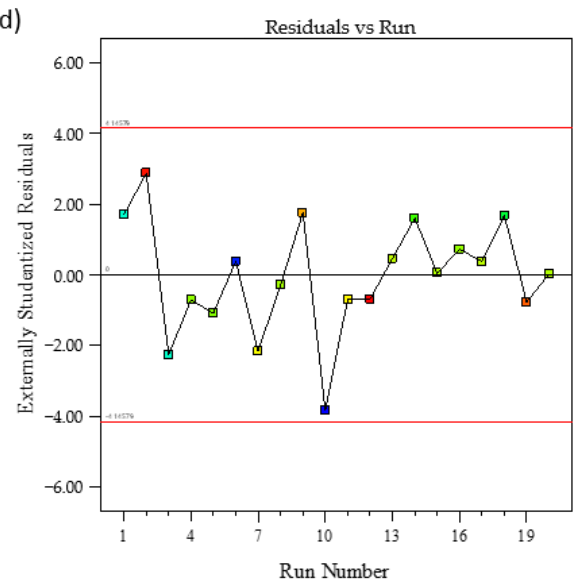

Figure 5. The $\mathrm{CCD}$ predicted value of $\mathrm{CO}_{2}$ removal efficiency vs. (a) actual absorption and (b) externally studentized residuals, and externally studentized residuals vs. (c) normal probability and (d) experiment run number.

Figure $5 \mathrm{~b}$ shows the residuals were equally dispersed inside the red line of the $\mathrm{x}$-axis without any trend. This scenario suggested the proposed models were acceptably free from any violation of the independence or constant variance assumption. Figure $5 c$ presents an analysis of the normal probability plot of residuals that provides additional info on the adequacy of the final model. The graph shows approximately linear residual distribution, 
which indicates uniform distribution of errors. Thus, the adequacy of the least-square fit was justified. Meanwhile, Figure $5 \mathrm{~d}$ shows the residual plots vs. experimental run order for $\mathrm{CO}_{2}$ solubility in aqueous MEA-[TBP][MeSO 3 ] solvent. As can be seen in the plot, there is a random scatter, providing assurance that no other lurking variables may have influenced the response during the experiment.

\subsubsection{Effect of the Variable Factors}

The effect of the variable factors and their interactions on $\mathrm{CO}_{2}$ solubility is shown in Figure 6. As seen in the perturbation plot in Figure 6a, temperature (curve B) and pressure (curve $\mathrm{C}$ ) are the significant factors affecting the $\mathrm{CO}_{2}$ solubility as compared to IL concentration (curve A). The analysis of variance summarized in Table 4 confirms these findings. Similar observations on the effect of IL addition into amine solution on $\mathrm{CO}_{2}$ solubility have been reported. $\mathrm{Xu}$ et al. suggest that the absorption of $\mathrm{CO}_{2}$ relies mainly on MEA, with little effect from IL, since adding salt might reduce the solubility of carbamate (resulting in MEA reacting with water) in a solution and hinder $\mathrm{CO}_{2}$ absorption. This process is known as the salting out effect. Despite the reduced $\mathrm{CO}_{2}$ solubility performance from the effect of IL concentration, the presence of IL may help in saving the energy during the regeneration process due to its lower heat capacity [13]. However, this work mainly focusses on the $\mathrm{CO}_{2}$ absorption of this hybrid solvent, and further study on the desorption process will be necessary in the future.

(a)

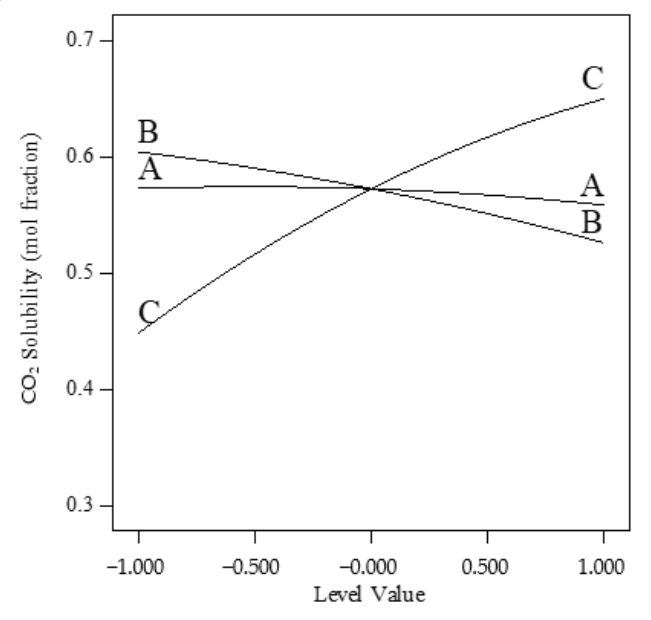

(c)

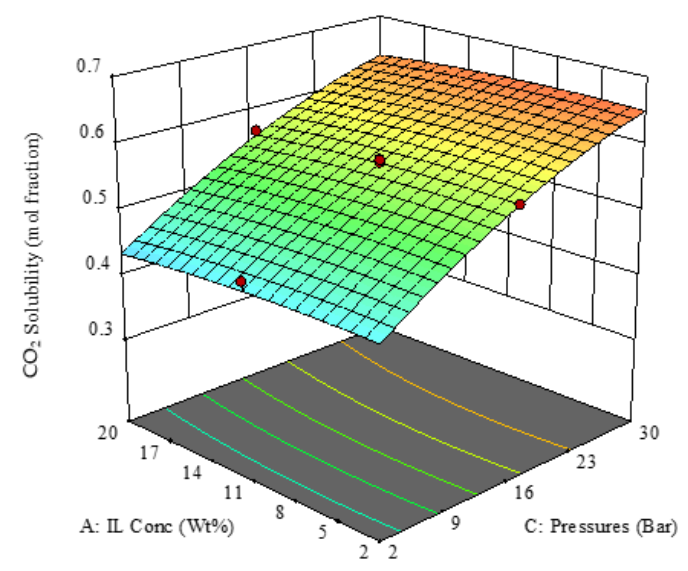

(b)

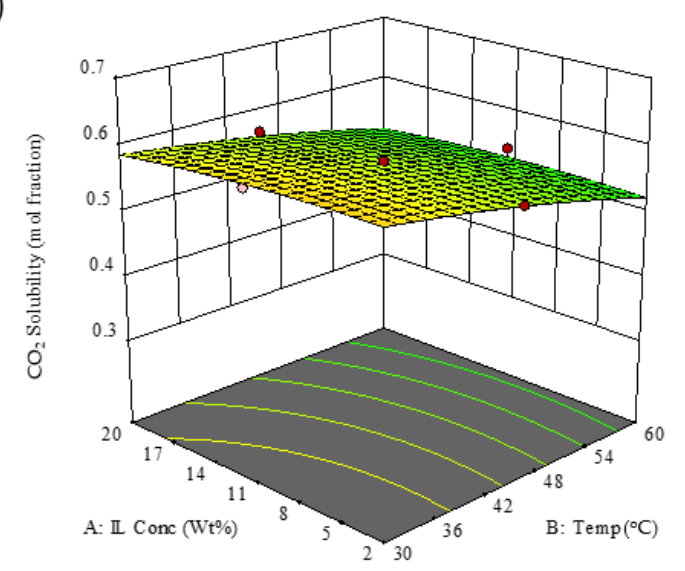

(d)

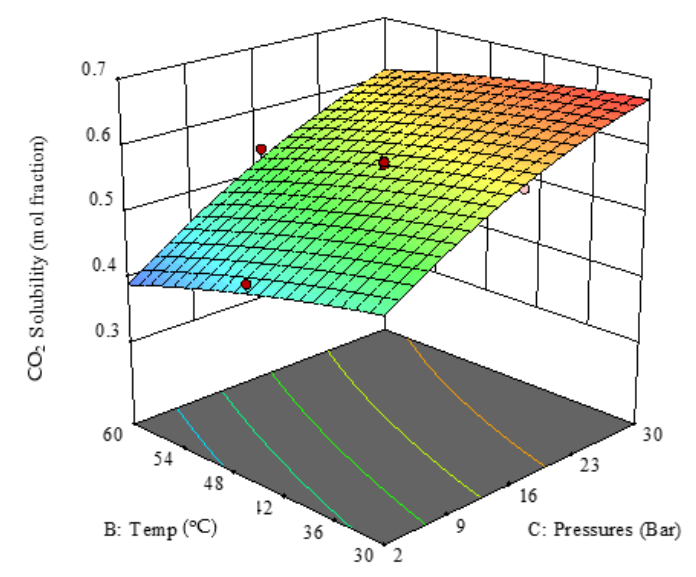

Figure 6. (a) Perturbation plot showing the effect of variable factors on $\mathrm{CO}_{2}$ solubility and the response surface plots of $\mathrm{CO}_{2}$ solubility as a function of (b) IL concentration and temperature, (c) IL concentration and pressure, and (d) pressure and temperature. 
From the perturbation plot, it is seen that an increase in temperature decreases the $\mathrm{CO}_{2}$ solubility, while an increase in pressure improves $\mathrm{CO}_{2}$ solubility; this is a trend that is consistent with gas solubility in ILs. As $\mathrm{CO}_{2}$ absorption involves an exothermic reaction, the chemisorption reaction decreases as the temperature increases. On the other hand, increasing the pressure of the gas increases the number of collisions between the $\mathrm{CO}_{2}$ molecules and the surface of the solution; hence, more gas is dissolved as the pressure increases $[25,26]$. It can be seen from the perturbation plot and the 3D response surface plots that pressure has the highest effect on $\mathrm{CO}_{2}$ solubility. RSM analyses also showed that no significant interactions took place between IL concentration and temperature, as shown in Figure $6 \mathrm{~b}$, and between IL concentration and pressure, as shown in Figure 6c. A significant interaction between temperature and pressure was detected, as seen in Figure 6d, which was indicated in the ANOVA table (Table 4). At high pressure, the effect of temperature on $\mathrm{CO}_{2}$ solubility was higher compared to the effect of temperature on $\mathrm{CO}_{2}$ solubility at lower pressure.

\subsubsection{Validation of Empirical Model Adequacy}

To ensure the developed empirical model was accurate, three validation experiments were implemented with new parameters, which were not tested during this experiment. The new parameters shown in Table 6 are within the ranges tested previously. The error ranging from $0.46 \%$ to $3.59 \%$ is within the $95 \%$ confidence interval. Hence, the model is acceptable, since the error is below 5.0\%. The cause of error might be from random error.

Table 6. Results of operating conditions with experimental design in confirmation runs.

\begin{tabular}{ccccccc}
\hline & \multicolumn{2}{c}{ Run Factor } & \multicolumn{3}{c}{ Mol Fraction } \\
\hline A: IL Concentration $(\mathbf{w t} \%)$ & B: Temperature $\left({ }^{\circ} \mathbf{C}\right)$ & C: $\mathbf{C O}_{\mathbf{2}}$ Pressure (bar) & Actual & Predicted & Error $(\%)$ \\
\hline 20 & 30 & 16 & 0.579 & 0.594 & 2.53 \\
\hline 20 & 45 & 2 & 0.439 & 0.437 & 0.46 \\
\hline 20 & 45 & 30 & 0.617 & 0.640 & 3.59 \\
\hline
\end{tabular}

\subsubsection{Optimization of $\mathrm{CO}_{2}$ Capture}

Table 7 shows the optimized parameter values to achieve maximum $\mathrm{CO}_{2}$ solubility in aqueous MEA-[TBP] $\left[\mathrm{MeSO}_{3}\right]$ solvent. Based on the suggested RSM model, the predicted maximum mol fraction of $\mathrm{CO}_{2}$ solubility in aqueous MEA-[TBP] $\left[\mathrm{MeSO}_{3}\right]$ solvent under optimum conditions is 0.670 . This value was only slightly higher as compared to the solubility of $\mathrm{CO}_{2}$ in $30 \mathrm{wt} \%$ aqueous MEA solution, where the mol fraction of $\mathrm{CO}_{2}$ solubility was found to be 0.613 under the same temperature and pressure conditions.

Table 7. Optimized condition for $\mathrm{CO}_{2}$ solubility in aqueous MEA-[TBP] $\left[\mathrm{MeSO}_{3}\right]$ solvent.

\begin{tabular}{cc}
\hline Factors & Value \\
\hline$[\mathrm{TBP}]\left[\mathrm{MeSO}_{3}\right]$ concentration & $2.093 \mathrm{wt} \%$ \\
Temperature & $30.36{ }^{\circ} \mathrm{C}$ \\
Pressure & $29.89 \mathrm{bar}$ \\
\hline
\end{tabular}

\section{Conclusions}

An absorption study of $\mathrm{CO}_{2}$ using an aqueous MEA-[TBP][MeSO 3$]$ hybrid solvent under different IL concentrations, temperatures and pressures was conducted. The density and viscosity showed an increasing trend at high IL concentration and a decreasing trend with increasing temperature. The FT-IR spectroscopy analyses show physical absorption of $\mathrm{CO}_{2}$ in [TBP][MeSO 3$]$, while chemical absorption of $\mathrm{CO}_{2}$ was detected in aqueous MEA and the hybrid solvents. The solubility $\mathrm{CO}_{2}$ study using RSM concluded that the most significant factor in $\mathrm{CO}_{2}$ solubility is pressure, followed by temperature. The IL 
concentration did not have a significant effect on the mol fraction of $\mathrm{CO}_{2}$ solubility. The validation of the experiment shows the quadratic model equation is within the acceptable range of error.

Author Contributions: Conceptualization, M.F.T. and A.I.; Data curation, M.U.Z.A. and N.M.M.Y.; Methodology, M.U.Z.A. and N.M.M.Y.; Project administration, M.F.T. and A.I.; Software, M.U.Z.A., M.F.T., N.M.M.Y. and S.M.M.G.; Writing—original draft, M.U.Z.A. and N.M.M.Y.; Writing—review and editing, M.F.T. All authors have read and agreed to the published version of the manuscript.

Funding: This research was funded by Yayasan Teknologi PETRONAS (YUTP), grant number 015LC0-074.

Institutional Review Board Statement: Not applicable.

Informed Consent Statement: Not applicable.

Conflicts of Interest: The authors declare no conflict of interest. The funders had no role in the design of the study; in the collection, analyses, or interpretation of data; in the writing of the manuscript, or in the decision to publish the results.

\section{References}

1. Gas 2020. Available online: https:/ /www.iea.org/reports/gas-2020 (accessed on 4 April 2021).

2. Haider, J.; Saeed, S.; Qyyum, M.A.; Kazmi, B.; Ahmad, R.; Muhammad, A.; Lee, M. Simultaneous capture of acid gases from natural gas adopting ionic liquids: Challenges, recent developments, and prospects. Renew. Sustain. Energy Rev. 2020, $123,109771$. [CrossRef]

3. Rochelle, G.T. Amine Scrubbing for $\mathrm{CO}_{2}$ Capture. Science 2009, 325, 1652-1654. [CrossRef]

4. Rufford, T.; Smart, S.; Watson, G.; Graham, B.; Boxall, J.; da Costa, J.D.; May, E. The removal of $\mathrm{CO}_{2}$ and $\mathrm{N}_{2}$ from natural gas: A review of conventional and emerging process technologies. J. Pet. Sci. Eng. 2012, 94-95, 123-154. [CrossRef]

5. Feng, Z.; Cheng-Gang, F.; You-Ting, W.; Yuan-Tao, W.; Ai-Min, L.; Zhi-Bing, Z. Absorption of $\mathrm{CO}_{2}$ in the aqueous solutions of functionalized ionic liquids and MDEA. Chem. Eng. J. 2010, 160, 691-697. [CrossRef]

6. Vega, F.; Cano, M.; Camino, S.; Fernández, L.M.G.; Portillo, E.; Navarrete, B. Solvents for carbon dioxide capture. In Carbon Dioxide Chemistry, Capture and Oil Recovery; Karamé, I., Ed.; IntechOpen: London, UK, 2018; p. 142.

7. Veawab, A.; Tontiwachwuthikul, P.; Chakma, A. Corrosion Behavior of Carbon Steel in the $\mathrm{CO}_{2}$ Absorption Process Using Aqueous Amine Solutions. Ind. Eng. Chem. Res. 1999, 38, 3917-3924. [CrossRef]

8. Hasib-Ur-Rahman, M.; Bouteldja, H.; Fongarland, P.; Siaj, M.; Larachi, F. Corrosion Behavior of Carbon Steel in Alkanolamine/ Room-Temperature Ionic Liquid Based $\mathrm{CO}_{2}$ Capture Systems. Ind. Eng. Chem. Res. 2011, 51, 8711-8718. [CrossRef]

9. Ramdin, M.; De Loos, T.W.; Vlugt, T.J. State-of-the-Art of $\mathrm{CO}_{2}$ Capture with Ionic Liquids. Ind. Eng. Chem. Res. 2012, 51, 8149-8177. [CrossRef]

10. Blanchard, L.A.; Hancu, D.; Beckman, E.J.; Brennecke, J.F. Green processing using ionic liquids and $\mathrm{CO}_{2}$. Nature 1999, 399, $28-29$. [CrossRef]

11. Shojaeian, A.; Haghtalab, A. Solubility and density of carbon dioxide in different aqueous alkanolamine solutions blended with 1-butyl-3-methylimidazolium acetate ionic liquid at high pressure. J. Mol. Liq. 2013, 187, 218-225. [CrossRef]

12. Camper, D.; Bara, J.E.; Gin, D.L.; Noble, R.D. Room-Temperature Ionic Liquid-Amine Solutions: Tunable Solvents for Efficient and Reversible Capture of $\mathrm{CO}_{2}$. Ind. Eng. Chem. Res. 2008, 47, 8496-8498. [CrossRef]

13. Xu, F.; Gao, H.; Dong, H.; Wang, Z.; Zhang, X.; Ren, B.; Zhang, S. Solubility of $\mathrm{CO}_{2}$ in aqueous mixtures of monoethanolamine and dicyanamide-based ionic liquids. Fluid Phase Equilibria 2014, 365, 80-87. [CrossRef]

14. Liu, Y.; Dai, Z.; Dai, F.; Ji, X. Ionic Liquids/Deep Eutectic Solvents-Based Hybrid Solvents for $\mathrm{CO}_{2}$ Capture. Crystals 2020, $10,978$. [CrossRef]

15. Azman, M.A.S. Investigation on the $\mathrm{CO}_{2}$ Solubility of Alkanolamine-ionic Liquid Hybrid Solvent; Final Year Project; Universiti Teknologi Petronas: Seri Iskandar, Malaysia, 2020.

16. Stolarska, O.; Soto, A.; Rodríguez, H.; Smiglak, M. Properties modification by eutectic formation in mixtures of ionic liquids. RSC Adv. 2015, 5, 22178-22187. [CrossRef]

17. Palgunadi, J.; Kang, J.; Cheong, M.; Kim, H.; Lee, H. Fluorine-Free Imidazolium-Based Ionic Liquids with a PhosphorousContaining Anion as Potential $\mathrm{CO}_{2}$ Absorbents. Bull. Korean Chem. Soc. 2009, 30, 1749-1754. [CrossRef]

18. Sun, C.; Dutta, P.K. Infrared Spectroscopic Study of Reaction of Carbon Dioxide with Aqueous Monoethanolamine Solutions. Ind. Eng. Chem. Res. 2016, 55, 6276-6283. [CrossRef]

19. Khan, S.N.; Hailegiorgis, S.M.; Man, Z.; Shariff, A.M.; Garg, S. Thermophysical Properties of Aqueous 1-Butyl-3Methylimidazolium Acetate [BMIM] [AC] + Monoethanolamine (MEA) Hybrid as a Solvent for $\mathrm{CO}_{2}$ Capture. Procedia Eng. 2016, 148, 1326-1331. [CrossRef]

20. Cheng, H.; Song, H.; Toan, S.; Wang, B.; Gasem, K.A.; Fan, M.; Cheng, F. Experimental investigation of $\mathrm{CO}_{2}$ adsorption and desorption on multi-type amines loaded HZSM-5 zeolites. Chem. Eng. J. 2021, 406, 126882. [CrossRef] 
21. Ma, C.; Pietrucci, F.; Andreoni, W. Capturing $\mathrm{CO}_{2}$ in Monoethanolamine (MEA) Aqueous Solutions: Fingerprints of Carbamate Formation Assessed with First-Principles Simulations. J. Phys. Chem. Lett. 2014, 5, 1672-1677. [CrossRef]

22. Morero, B.; Groppelli, E.S.; Campanella, E.A. Evaluation of biogas upgrading technologies using a response surface methodology for process simulation. J. Clean. Prod. 2017, 141, 978-988. [CrossRef]

23. Abdulredha, M.M.; Hussain, S.A.; Abdullah, L.C. Optimization of the demulsification of water in oil emulsion via non-ionic surfactant by the response surface methods. J. Pet. Sci. Eng. 2020, 184, 106463. [CrossRef]

24. Pashaei, H.; Ghaemi, A.; Nasiri, M.; Karami, B. Experimental Modeling and Optimization of $\mathrm{CO}_{2}$ Absorption into Piperazine Solutions Using RSM-CCD Methodology. ACS Omega 2020, 5, 8432-8448. [CrossRef] [PubMed]

25. Shariff, A.; Shaikh, M.S.; Bustam, M.; Garg, S.; Faiqa, N.; Aftab, A. High-pressure Solubility of Carbon Dioxide in Aqueous Sodium L-Prolinate Solution. Procedia Eng. 2016, 148, 580-587. [CrossRef]

26. Maginn, E. Ionic Liquids: Breakthrough Absorption Technology for Post-Combustion $\mathrm{CO}_{2}$ Capture; Technical Report; Office of Scientific and Technical Information (OSTI): Oak Ridge, TN, USA, 2012. 